\title{
石英ガラス表面の電子線照射による脆性制御
}

\author{
山口 直 樹 $^{1, *} \quad$ 小 栗 和 也 ${ }^{2} \quad$ 利根川 $\quad$ 昭 $^{2} \quad$ 西＼cjkstart義 武 1
}

\author{
1東海大学大学院工学研究科金属材料工学専攻 \\ 2 東海大学理学部物理学科
}

J. Japan Inst. Metals, Vol. 68, No. 3 (2004), pp. 198-201 (C) 2004 The Japan Institute of Metals

\section{Brittleness Control of Silica Glass Surface Irradiated by Sheet Electron Beam}

\author{
Naoki Yamaguchi ${ }^{1, *}$, Kazuya Oguri ${ }^{2}$, Akira Tonegawa ${ }^{2}$ and Yoshitake Nishi ${ }^{1}$ \\ ${ }^{1}$ Department of Materials Science, Tokai University, Hiratsuka 259-1292 \\ ${ }^{2}$ Department of Physics, Tokai University, Hiratsuka 259-1292
}

\begin{abstract}
Influences of sheet electron beam irradiation on brittleness, fracture load and fracture toughness were studied for silica glass surface. The irradiation, which is one of short-time treatments at low temperature below boiling point of water, restrained the brittleness and enhanced fracture load and fracture toughness of silica glass surface. The brittleness restrain can be explained by the stress relaxation, which was induced by increase in free volume related to dangling bonds.
\end{abstract}

(Received September 3, 2003; Accepted December 24, 2003)

Keywords: silica glass, electron beam, brittleness, toughness, free volume, dangling bond

\section{1. 緒言}

金属ガラスは溶融金属を凝固時に遠心力を加え, ガラス遷 移温度以下の温度まで急速に冷却するフィラメントキャステ ィング法の発明により, 再現性よく均質なリボン状試料を作 製可能にした時点で, 本格的な研究が開始された ${ }^{1-3)}$. さら に, 高音質を達成したウオークマンや高画質ビデオのヘッド 等に応用され，一挙に実用材料としての地位を確立した。こ の間, 製造プロセスの基礎的研究が行われ非晶質形成の臨界 冷却速度の測定 ${ }^{4,5)}$, 磁性 ${ }^{6)}$, 硬さ ${ }^{7)}$, 耐食性 ${ }^{8)}$, イオン加工 速度 ${ }^{9}$ の冷却速度依存性に関する基礎的研究が行われた。さ らに, 冷却速度が速いと平均原子間距離は増加し, 配位数が 低下することにより, 平均原子容が増加することを確認して いる10)。これら一連の結果は, 高冷却速度で液体から急速 冷却処理することにより得られる原子構造の変化が，大きな 冷却速度依存性を示す諸物性の支配因子となっていることを 示している. ところで, 実用的に用いられる大面積のリボン 状試料では高速冷却の際に冷却条件を均質にするのが困難で ある. 不良率を低下させ, 安定した物性を得るためには熱処 理を施す場合もある。しかしながら熱処理では脆化だけでな く耐食性や飽和磁束密度6)の劣化も生じ, たとえ製品化には 問題はなくても，金属ガラスの軟磁性を十分発揮できない場 合もあった ${ }^{6)}$. そこで, 金属ガラス表面にショットピーニン グを施すことにより11), 平均原子間距離を増加, 配位数を 低下させ平均原子容を増加させ, 原子構造をより乱れさせる 方法を提案した。すなわち，得られた金属ガラスの磁

\footnotetext{
* 東海大学大学院生 (Graduate Student, Tokai University)
}

性 $^{12)}$, 変形抵抗 ${ }^{13,14)}$, 耐食性 ${ }^{15)}$ は, より高速冷却速度で凝固 した試料の物性值に対応し, 均質化処理としても優れている ことを示した．これは，金属ガラスの物性が熱処理やショッ トピーニングにより自由に制御が可能であることも示してい る.

一方, ガラス構造を持つセラミックスは数千年前から宝飾 品や高級食器として用いられ, 現在も建築構造, 電気機器, 自動車等の空に広く材料として使われている. 有史以来, ガ ラス状セラミックスの脆性は添加元素と熱処理による残留応 力の開放によって改善され, 均質な材料を供給できる技術が 確立されて来ている．しかしながら，もし成分を変えずに成 型後, クラックが発生し易い表面において, 破壊や傷を付け ずに脆性を均質に改善することが可能であれば，その手段は 先端技術で望まれている高強度極薄ガラスの革新的製造プロ セスとなりえる. そこで, 本研究では, 電子線照射を行うこ とにより, 石英ガラス中のシリコンと酸素の結合が切れ, 不 対電子が形成されることに着目した. さらに, 不対電子を伴 う自由体積が応力緩和を誘起すると仮定すると, 石英ガラス の脆性が電子線照射により制御しうると予測し, 研究を行っ た。

\section{2. 実 験 方 法}

\section{1 電子線照射}

Fig. 1 に本実験で用いた電子線 (EB) 照射処理装置の模式 図を示す，EB 照射処理装置は株式会社岩崎電気エレクトロ カーテンプロセッサーを用いた(TypeＣB175/15/180L， Energy Science Inc., Woburn, MA, Iwasaki Electric Group 


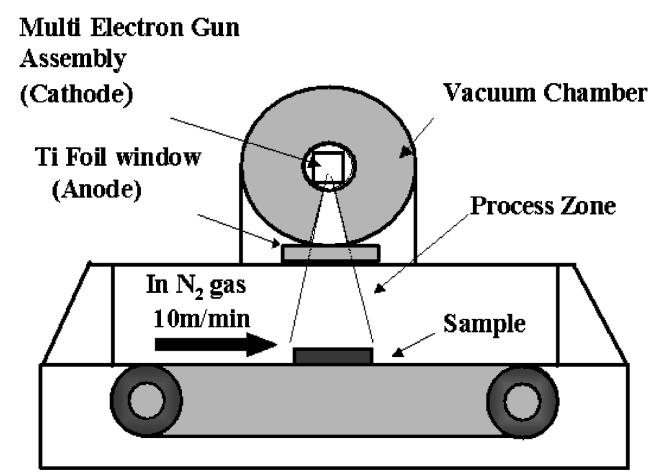

Fig. 1 Schematic diagram of electron-curtain processor (Type CB175/15/180L, Energy Science Inc., Woburn, MA, Iwasaki Electric Group Co. Ltd. Tokyo).

Co. Ltd. ${ }^{16-20)}$. 本装置の特徵は, 一般的な EB 照射装置と は異なり大気圧下で EB 照射を行えることにある，また，照 射線量はビーム電流とコンベア速度により制御するため, $\mathrm{EB}$ をパルス的に照射できる。このため， EB 照射のエネル ギーを他の $\mathrm{EB}$ 照射装置よりも低く抑えることができ, 試料 の温度が極端に上昇しない点も特徵である. EB 照射処理条 件は加速電圧 $170 \mathrm{kV}$, 印加電流 $2.0 \mathrm{~mA}$, EB 照射処理雾囲 気は酸素濃度 $400 \mathrm{ppm}$ 以下, 窒素䨌囲気 (大気圧下, 残留酸 素 $400 \mathrm{ppm}$ 以下）とした． EB 照射は一回の照射時間を 0.23 秒に一定とし, 表面温度をコントロールした. 試料はコンベ アスピード $9.56 \mathrm{~m} / \mathrm{min}$ で処理した. 照射線量の算出法を式 (1) 16-20)に示す.

Dose $(\mathrm{MGy})=0.216 \times I(\mathrm{~mA}) / S(\mathrm{~m} / \mathrm{min}) \times N($ time $)$ 照射線量の校正は FAR WEST TECHNOLOGY, INC. 製の ナイロンフィルム検出器を用いた. 電子行程 $(S: \mu \mathrm{m})$ と電 子の加速電圧 $(V: \mathrm{kV})$ と物質の密度 $\left(\rho: \mathrm{cm}^{3}\right)$ は式 $(2)$ の関 係があることが知られている ${ }^{21)}$.

$$
S=\frac{66.7}{\rho} V^{5 / 3}
$$

ここで, 電子線通過に伴う電压降下を考慮する必要がある. 式 ( 2 ) は電圧と距離の関数であることから, 電子線通過に 伴う電圧降下を電子行程距離とチタン薄板の厚さより算出 し, さらに窒素ガス層についても同様に計算を行い, 試料表 面での電位の算出を行った. 本装置の電子線照射空はチタン 製(密度： $4540 \mathrm{~kg} / \mathrm{m}^{3}$ )であり, 厚さが $10 \mu \mathrm{m}$ の薄板を使用 している. また照射空から試料間は大気圧の窒素ガス(密 度 : $1.13 \mathrm{~kg} / \mathrm{m}^{3}$ ) で満たされていることから, 電子の運動工 ネルギーはフィラメント発生時の $170 \mathrm{keV}$ から, 試料表面 での $128 \mathrm{keV}$ まで低下した. 今回用いた石英ガラスの密度 $\rho$ は $2220 \mathrm{~kg} / \mathrm{m}^{3}$ である。これらの值から式 (2)で計算する と, 石英ガラスへの $\mathrm{EB}$ 侵入深さは $100 \mu \mathrm{m}$ である.

\section{2 脆性評価法}

ビッカース硬度計を用い, 硬さと, 表面破壊時の微視的機 械的性質を評価した ${ }^{22)}$. 同一荷重で 5 点試験を行い, 1 点で もクラックが生じる時の最大荷重を $P_{\mathrm{f}}^{\mathrm{min}}$, そのときの圧痕 径を $d_{\mathrm{f}}^{\min }$ とし, 同一荷重で 5 点試験を行った時, 1 点でも クラックが生じなかった最小荷重を $P_{\mathrm{f}}^{\max }$, そのときの圧痕 径を $d_{\mathrm{f}}^{\max }$ とし，それぞれの中点を $P_{\mathrm{f}}, d_{\mathrm{f}}$ とした ${ }^{22)}$.すなわ

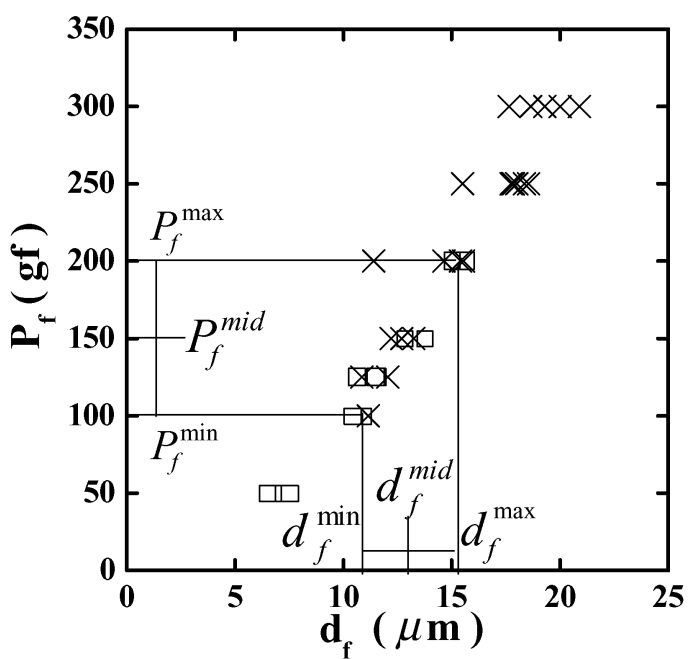

Fig. 2 Change in indentation load $(\mathrm{P})$ of silica glass against indentation diameter (d) of Vickers, indentation tester.

ち, 破壊時の塑性変形歪の指標である臨界圧痕径 $\left(d_{\mathrm{f}}\right)$ と破壊 時の塑性変形荷重の指標である臨界圧痕荷重 $\left(P_{\mathrm{f}}\right)$ の測定結果 から, 表面に抢ける勒性の指標である破壊時の臨界圧痕塑性 変形エネルギー $\left(E_{\mathrm{f}}\right)$ を導出した ${ }^{22)}$. Fig. 2 に EB 照射線量 $0.864 \mathrm{MGy}$ の時の臨界圧痕径 $\left(d_{\mathrm{f}}\right)$ と臨界圧痕荷重 $\left(P_{\mathrm{f}}\right)$ の関係 を示した. 通常の $K_{1 \mathrm{C}}$ 測定が不可能な非常に脆い材料に利 用される強勒性の指標である臨界圧痕塑性変形エネルギー $\left(E_{\mathrm{f}}\right)$ を式 $(3)$ を用いて算出した ${ }^{22)}$.

$$
E_{\mathrm{f}}^{\mathrm{mid}}=C P_{\mathrm{f}}^{\mathrm{mid}} d_{\mathrm{f}}^{\text {mid }} / 3
$$

$C$ は定数 $(C=h[$ 圧痕深さ $] / d[$ 圧痕径 $]=0.143)$ である. 一般 的な応力拡大係数 $K_{1 \mathrm{C}}$ は破壊勒性を示す一般的な指標であ る. 通常の引張試験ではクラックの発生と同時に破壊が終了 するような, 加工が困難な, 非常に脆い試料で適用可能な式 (4)を用いて $K_{1 \mathrm{C}}$ の值は $E_{\mathrm{f}}$ から求められる 22 .

$$
\log _{10} K_{1 \mathrm{C}}=0.44 \log _{10} E_{\mathrm{f}}^{\mathrm{mid}}-0.63
$$

\section{3 不対電子の評価方法}

$\mathrm{EB}$ 照射による不対電子(ダングリングボンド)の生成は電 子スピン共鳴装置(日本電子株式会社製 JES-FA200)を用い て測定を行った ${ }^{16)}$. 測定条件は, X-band(周波数： 9.4 9.5 $\mathrm{GHz}), 100 \mathrm{kHz}$ 磁場変調, 室温で行った. スピン数の算出 には, 標準試料として $\mathrm{Mn}^{2+}$ を用いた。 スピン数の算出は, $\mathrm{Mn}^{2+}$ のスペクトル強度と試料のスペクトル強度を比較する ことにより求めた．な扔，試料は原則として $1 \mathrm{~mm} \times 5 \mathrm{~mm}$ 程度面積の大きさとし, 石英製試料チューブ内に充填し測定 を行った。

\section{4 動径分布関数}

電子線照射により不対電子の生成が確認でき, 原子間距離 と配位数が変化したことが推測できる.よって，X 線回折 を行い, 動径分布関数 (RDF) を算出した ${ }^{10,11,23)}$. X 線回折に 際して, 回転対陰極方式の MoX 線源を用い, ディフラクト メータ法(ステップスキャニング), Mo-K $\alpha$ を Niフィル ターで選別, 出力電圧は $50 \mathrm{kV}$, 出力電流は $70 \mathrm{~mA}$, 回折 幅は $0.05 \mathrm{deg} / \mathrm{step}, \mathrm{X}$ 線計測時間は $10 \mathrm{~s} / \mathrm{step}$, 回折角度は $2^{\circ} \sim 144^{\circ}(2 \theta)$ とした. 


\section{3. 結 果と考察}

\section{1 石英ガラスの電子線照射処理前後の強度評価}

微小な塑性変形抵抗への電子線照射の効果を評価するため に, ビッカース硬さを測定した. Fig. 3 中の点線に電子線照 射線量と硬さ $(\mathrm{Hv})$ の関係を示した。照射線量が増加しても $\mathrm{Hv}$ が変化しないことを確認した。このことは，石英ガラス 表面は電子線照射により硬化しないことを示している.

破壊に至るまでの塑性変形丕, すなわち延性への電子線照 射の効果を評価するために，ビッカース硬度計の圧痕にクラ ックが生じた時の圧痕径を測定した. Fig. 3 破線に電子線照 射線量と破壊時の塑性変形歪の指標である臨界圧痕径 $\left(d_{\mathrm{f}}\right)$ の 関係を示したＨv とは異なり，0.86 MGyまでの照射線量 の増加に伴い $d_{\mathrm{f}}$ が $20 \%$ 増大することを確認した。このこと は，石英ガラス表面の脆性を電子線照射が改善したことを示 している.

破壊に至るまでの塑性変形荷重, すなわち表面微小破壊荷 重への電子線照射の効果を評価するために, ビッカース硬度 計の圧痕にクラックが生じた時の荷重を測定した. Fig. 3 の 一点鎖線に電子線照射線量と破壊時の塑性変形荷重の指標で ある臨界圧痕荷重 $\left(P_{\mathrm{f}}\right)$ の関係を示した。 $d_{\mathrm{f}}$ と同様に, 0.86 MGy までの照射線量の増加に伴い $P_{\mathrm{f}}$ は $56 \%$ 増大すること を確認した。これは, 弾性の指標となる硬さが変化しないの に, 石英ガラス表面の脆性が電子線照射により改善されたこ とにより，破壊が発生せず，表面の破壊強度が増大したこと を示している.

破壞に至るまでの塑性変形仕事, すなわち表面微小破壊工 ネルギーへの電子線照射の効果を評価するために，ビッカー 久硬度計の圧痕にクラックが生じた時の荷重と圧痕径の值か ら式(3)を用いて計算した. Fig. 3 の二点鎖線に電子線照射

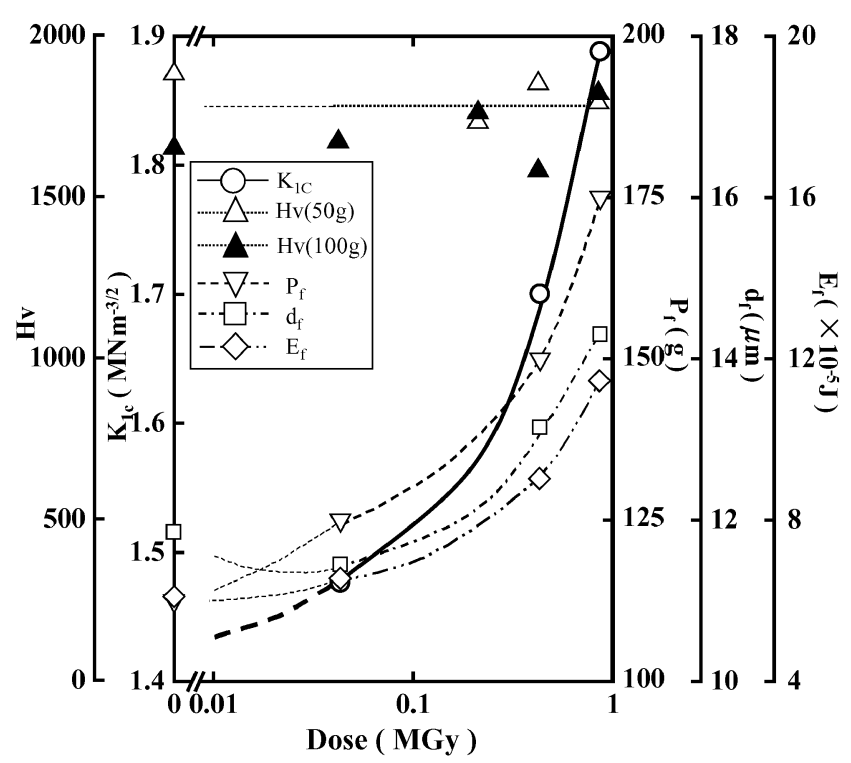

Fig. 3 Changes in micro-Vickers, hardness (Hv), critical diameter $\left(d_{\mathrm{f}}\right)$ of indentation on fracture, critical load $\left(P_{\mathrm{f}}\right)$ of indentation on fracture, critical plastic deformation energy $\left(E_{\mathrm{f}}\right)$ of indentation on fracture, fracture toughness values of $K_{1 \mathrm{C}}$ of silica glass against electron beam irradiation dose (MGy).
線量と破壊のための臨界圧痕塑性変形エネルギー $E_{\mathrm{f}}$ の関係 を示した. $0.86 \mathrm{MGy}$ をでは照射線量の増加に伴って $E_{\mathrm{f}}$ は 88\%増加した。

次に, 破壊勒性を示す一般的な指標である応力拡大係数 $K_{1 \mathrm{C}}$ を用いて電子線照射によるシリカガラス表面の強勒化の 程度を評価した. そのため, 非常に脆い試料で適用可能な式 (4)を用いて $K_{1 \mathrm{C}}$ の值は $E_{\mathrm{f}}$ の值から求めた ${ }^{22)}$. Fig. 3 中の 実線に電子線照射線量と応力拡大係数 $K_{1 \mathrm{C}}$ の関係を示す. $0.86 \mathrm{MGy}$ までの範囲で照射線量の増加に伴い， $K_{1 \mathrm{C}}$ も $32 \%$ 増加した。 以上の結果を縓めると, 電子線照射は破壊に必要 な臨界圧痕径 $\left(d_{\mathrm{f}}\right)$, 臨界圧痕荷重 $\left(P_{\mathrm{f}}\right)$, 臨界圧痕塑性変形工 ネルギー $E_{\mathrm{f}}$, 応力拡大係数 $K_{1 \mathrm{C}}$ を増加させ, 石英ガラスの 脆性を改善した．ここで, 硬さの変化が少ないことからも, 石英ガラス表面の破壊強さの指標である臨界圧痕荷重 $\left(P_{\mathrm{f}}\right)$ 值 増大の主たる原因は, 臨界圧痕径 $\left(d_{\mathrm{f}}\right)$ の増大, すなわち, 試 料表面の脆性が改善されたことにある.すなわち，石英ガラ ス表面の強勒性の指標である臨界圧痕塑性変形エネルギー $E_{\mathrm{f}}$, さらに, 応力拡大係数 $K_{1 \mathrm{C}}$ 值増大の主たる原因も, 臨 界圧痕径 $\left(d_{\mathrm{f}}\right)$ の増大, すなわち, 試料表面の脆性が改善され たことで説明できる。

\section{2 電子線照射による不対電子の生成}

電子線照射によるシリカガラス試料表面の脆性改善が強勒 化の支配因子であることが確認出来た。そこで，電子線照射 による脆性改善の機構を考察する. シリコン原子と酸素原子 が強固に結合している石英ガラス構造が外力を受けると割れ やすい. 一方, 不対電子を伴う自由体積が存在すると応力が 緩和する可能性が高く, 脆性が改善される可能性が高い. そ こで，電子線照射による不対電子の形成を確認するために， 電子スピン共鳴装置 (ESR) スペクトルを用いて不対電子の 存在に伴うシグナルを確認した. Fig. 4 に電子線照射処理前 後による石英ガラスの ESR スペクトルを示す．未照射では シグナルは確認されず，石英ガラス中に不対電子が存在しな いことを確認した。一方, 電子線照射した試料ではスペクト

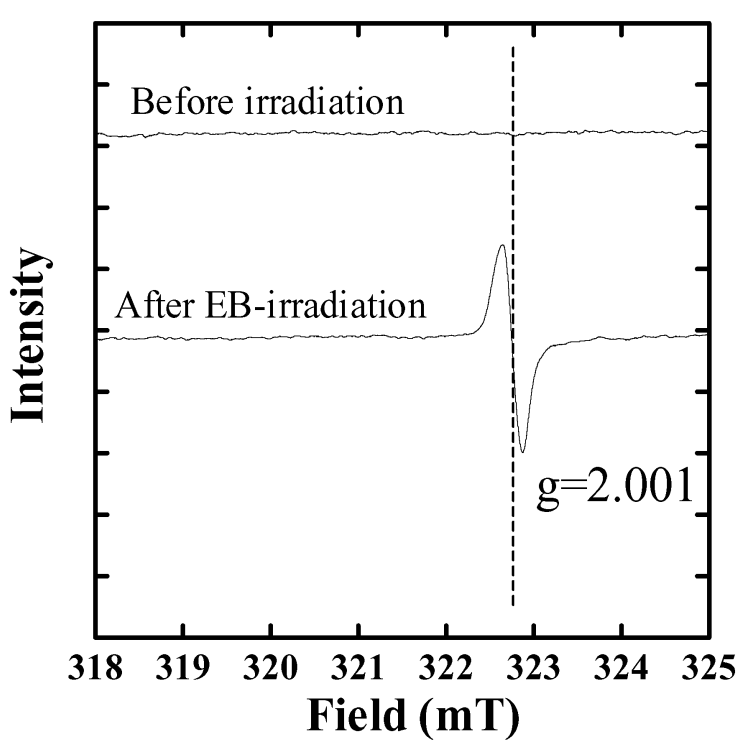

Fig. 4 ESR signals of silica glass before and after electron beam irradiation. 
ルが見られ, 不対電子の生成が確認できた. また, スペクト ルの $g$ 值から, 生成された不対電子はシリコン原子と酸素原 子の結合が切れた $\mathrm{E}$ プライムセンターの不対電子であるこ とを確認した ${ }^{24,25)}$. 電子線照射により, シグナルは高まり, 不対電子の増加が確認された。これは, 石英ガラス中の自由 体積の増加を意味し, 外部応力が作用した場合, 応力緩和が 働く可能性が高いと推察される.

\section{3 動径分布関数による自由体積の評価}

金属ガラスに関して自由体積が増大すると平均原子間距離 が増大し配位数が減少することを確認している10,11). 一方, 電子線照射によりシリカガラス中に不対電子を伴う自由体積 が増加する可能性が高い。 その結果, 平均原子間距離は増大 し, 配位数が減少することが予想される.そこで, X 線回 折の測定結果から動径分布関数 (RDF)を算出した ${ }^{10,23)}$. Fig. 5 に電子線照射前後のシリカガラス表面における RDFを示 した. 電子線照射を行うと, わずかに動経分布関数が変化し ていることがわかる. 次に RDF の結果から, EB 照射前後 の換算平均原子間距離と換算配位数を求めた. 電子線照射前 の換算平均原子間距離と換算配位数をそれぞれ $r_{0}, N_{0}$ とし 照射後を $r_{\mathrm{D}}, N_{\mathrm{D}}$ とし変化率 $r_{\mathrm{D}} / r_{0}, N_{\mathrm{D}} / N_{0}$ を算出した. $\mathrm{Si}-$ $\mathrm{O}$ の換算原子間距離は, $\mathrm{EB}$ 照射により $0.3 \%$ 増加してい る. 一方, $\mathrm{Si}-\mathrm{O}$ の換算配位数は照射により $6 \%$ 減少してい る. よって, 電子線照射による脆性改善機構は不対電子を伴 う自由体積の増加により誘起される応力緩和機構が支配因子 である可能性が高いことを確認した．すなわち，石英ガラス に電子線照射を行い, 不対電子を伴う自由体積が生成され, 応力緩和機構が働く．それに伴い破壊歪が増加することによ って $K_{1 \mathrm{C}}$ が増加し, 強靶化したと結論付けられる.

最近, 電子線と同様に, イオン照射により脆性が改善され ることも, 知られている ${ }^{26)}$. 電荷しか残留しない電子線照 射と，イオン照射が大きく異なる所は，イオン粒子が残留 し，これが表面に圧縮応力を発生させることにより，脆性が 改善されると大雑把に考察されている. 我々の研究グループ でもセラミックスにイオン照射を行った経験がある ${ }^{27)}$.こ

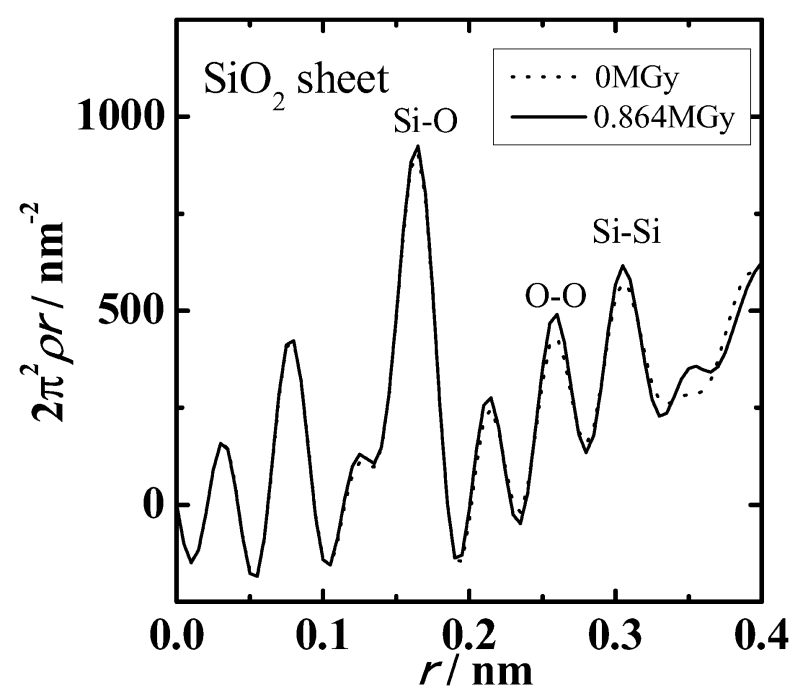

Fig. 5 Results of radial distribution function (RDF) before and after electron beam irradiation.
こでは, 経年変化により, 導入原子が構造の変化を引き起こ し，利点もあるが，場合によっては経年変化とともに微量の ガスが排出し，医療現場において重大な問題を引き起こす可 能性を有する知見が得られている. さらに, 機構解明を考察 する場合, 残留イオンの引き起こす機構は電子線よりも変数 が多く, 原子オーダーの考察では複雑な機構となる可能性が 高い. この点, 電子線照射は単純な自由体積の緩和機構で説 明できることが特徵である。

\section{4. 結 論}

電子線照射により石英ガラス表面の脆性改善に成功した. ESR と X 線の動径分布関数の結果から, 電子線処理の脆性 改善機構は不対電子を伴う自由体積増加による応力緩和が支 配因子である可能性が高いと結論付けた。

\section{文献}

1) T. Masumoto and R. Maddin: Acta Metall. 19(1971) 725-741.

2) K. Masumoto: J. of Japan Inst. Metals 15(1976) 194-202.

3) M. Naka, K. Hasimoto and K. Masumoto: J. Japan Inst. Metals 5 (1976) 188-194.

4) Y. Nishi, N. Kayama, S. Kiguchi, K. Suzuki and K. Masumoto: J. Japan Inst. Metals 44(1980) 1336-1341.

5) Y. Nishi, K. Suzuki and K. Masumoto: J. Japan Inst. Metals 45 (1981) 1300-1305.

6) Y. Nishi, T. Kai, M. Tachi, T. Ishidaira and E. Yajima: Scri. Metall. 20 (1986) 1099-1100.

7) Y. Nishi and H. Harano: J. Mater. Sci. Lett. 6 (1987) 1445-1446.

8) Y. Nishi, T. Kai, M. Suzuki and K. Iguchi: J. Mater. Sci. Lett. 6(1987) 961-962.

9) Y. Nishi, N. Inoue, T. Shibayama, K. Nakamura, I. Inoue, T. Kai and T. Shima: J. Mater. Sci. Lett. 5(1986) 1287-1288.

10) Y. Nishi, H. Harano, S. Uchida and K. Oguri: J. Mater. Sci. 25 (1990) 4477-4482.

11) Y. Nishi, H. Harano, T. Fukunaga and K. Suzuki: Phys. Rev. B 37 (1988) 2855-2860.

12) Y. Nishi and H. Harano: J. Appl. Phys. 63 (1988) 1141-1143.

13) Y. Nishi, H. Harano and H. Ishizuki: Mater. Sci. Eng. 98(1988) 505-507.

14) S. Uchida, O. Shibata, K. Oguri and Y. Nishi: J. Mater. Sci. 29 (1994) 5589-5592.

15) Y. Nishi, A. Yazawa, C. Seshimo and K. Oguri: J. Mater. Sci. Lett. 15(1996) 1582-1583.

16) Y. Nishi, T. Toriyama, K. Oguri, A. Tonegawa and K. Takayama: J. Mater. Res. 16 (2001) 1632-1635.

17) Y. Nishi, H. Izumi, J. Kawano, K. Oguri, Y. Kawaguchi, M. Ogata, A. Tonegawa, K. Takayama, T. Kawai and M. Ochi: J. Mater. Sci. 32 (1997) 3637-3639.

18) K. Oguri, K. Fujita, M. Takahashi, Y. Omori, A. Tonegawa, N. Honda, M. Ochi, K. Takayama and Y. Nishi: J. Mater. Res. 13 (1998) 3368-3371.

19) Y. Nishi, S. Takagi, K. Yasuda and K. Itoh: J. Appl. Phys. 70(1991) 367-370.

20) Y. Nishi, S. Takagi and K. Yasuda: Phys. Lett. A 141(1989) 294-296

21) G. Wakalopulos: Radtech Report, July/August (1998) 10-15.

22) Y. Nishi, T. Katagiri, T. Yamano, F. Kanai, N. Ninomiya, S. Uchida and T. Morishita: Appl. Phys. Lett. 58(1991) 20842086.

23) T. Fukunaga: Engi. Dr. thesis, Tohoku University (1979) 5563.

24) D. L. Griscom and E. J. Friebele: Rad. Effects 65(1982) 303312.

25) D. L. Griscom: The Centenial Memorial Issue of the Ceramic Soc. Jpn 99 (1991) 923-942.

26) Z. Toth, E. Rudnayova, A. Juhasz, G. Peto and J. Lendvai: Key Eng. Mater. 223(2002) 47-54.

27) Y. Nishi, Y. Takahashi, S. Takagi, T. Sudo, N. Inoue and T. Shima: Phys. Rev. B 46(1992) 454-456. 